\title{
Plasma Glucagon-Like Peptide-1 and Cholecystokinin Responses to Fast Food in Healthy-Weight and Obese Men
}

\section{Respon Glucagon-Like Peptide-1 dan Kolesistokinin terhadap Makanan Siap Saji pada Pria Status Gizi Normal dan Obesitas}

\author{
Dian Handayani ${ }^{1}$, Dianita Setya $P P^{2}$, Hidayat Sujuti ${ }^{3}$, Sri Andarini ${ }^{4}$, Widya Rahmawati ${ }^{5}$, Inggita Kusumastuty ${ }^{6}$, Leny \\ Budhi $H^{7}$, Nindy Sabrina ${ }^{8}$ \\ ${ }^{1,5,6,7}$ Department of Nutrition Faculty of Medicine Universitas Brawijaya Malang \\ ${ }^{2}$ Magister in Biomedical Science Program Faculty of Medicine Universitas Brawijaya Malang \\ ${ }^{3}$ Department of Biochemistry Faculty of Medicine Universitas Brawijaya Malang \\ ${ }^{4}$ Department of Public Health Faculty of Medicine Universitas Brawijaya Malang \\ ${ }^{8}$ Nutrition Program Faculty of Food Technology and Health Universitas Sahid Jakarta
}

\begin{abstract}
Satiety hormones play a role in obesity metabolism. The satiety response to similar nutrients in food in healthy and obese men remains undefined. The research was aimed to determine the satiety response differences by comparing the effect of isocaloric fast-food consumption on reducing appetite-related gut hormones, such as glucagon-like fullness ratings and both GLP-1 and CCK among healthy and obese men. Respondents were given an isocaloric fast food, then GLP-1 and CCK levels were measured using enzyme-linked immunosorbent assay (ELISA). Visual analogue scale (VAS) form was used for hunger and fullness ratings of the subjects. The difference level of GLP-1,CCK, and VAS between groups were measured by t-test. The correlation between VAS hunger and fullness rating was measured by Pearson. Plasma hormone levels in 16 obese and 16 healthy-weight respondents were assessed before eating and at 30, 60, and 120 minutes after consumption. In obese men, GLP-1 levels were significantly higher than those in healthy-weight men at 60 and 120 minutes, while healthy-weight men had significantly higher CCK levels than those of obese men over time (all $p<0.05$ ). The total area under the curve (AUC) for GLP-1 was significantly higher for obese men than for healthy-weight men, while the AUC for CCK was significantly higher for healthy-weight men than for obese men. Obese men have higher plasma GLP-1 levels and lower plasma CCK than healthy men indicates that those respondents were experiencing glucose intolerance and leptin alteration. The hormonal systems that may contribute to the development of obesity need further investigation.
\end{abstract}

Keywords: Cholecystokinin, glucagon-like peptide 1, obesity, visual analogue scale of hunger, visual analogue scale of fullness

\begin{abstract}
ABSTRAK
Hormon satiety berperan pada metabolisme obesitas. Respon kenyang terhadap makanan dengan kandungan zat gizi yang hampir sama pada pria dengan status gizi normal dan obesitas masih belum pernah dijelaskan. Penelitian ini bertujuan mengetahui perbedaan respon kenyang dengan membandingkan efek konsumsi makanan siap saji isokalori terhadap gut hormon yang berperan pada penurunan nafsu makan, seperti glucagon-like peptide (GLP-1) dan kolesistokinin (CCK) pada pria dengan status gizi normal dan obesitas. Responden diberi makanan makanan siap saji isokalori, lalu dilakukan pengukuran kadar GLP-1 dan CCK dengan menggunakan metode ELISA. Respon subjektif menggunakan formulir visual analogue scale (VAS) untuk skala lapar dan kenyang. Perbedaan kadar GLP-1, CCK dan VAS antar kelompok dianalisis dengan menggunakan uji beda t-test. Hubungan antara skala visual analog rasa lapar dan kenyang dengan GLP-1 dan CCK dianalisis dengan menggunakan metode Pearson. Kadar hormon plasma pada 16 responden obesitas dan 16 responden status gizi normal diukur sebelum makan dan pada menit ke-30, 60, serta 120 setelah makan. Pada responden obesitas, kadar GLP-1 lebih tinggi secara signifikan daripada responden status gizi normal pada menit ke-60 dan 120, sedangkan kadar CCK tiap waktu yang lebih tinggi ditemukan pada responden status gizi normal. Total area bawah kurva (AUC) untuk CCK lebih tinggi secara signifikan pada responden status gizi normal. Pria obesitas memiliki kadar plasma GLP-1 yang lebih tinggi dan kadar CCK plasma yang lebih rendah yang menunjukkan kondisi intoleransi glukosa dan perubahan kadar leptin. Hasil penelitian ini inmenunjukkan mekanisme sistem hormon secara spesifik pada perkembangan obesitas masih memerlukan penelitian lebih lanjut.
\end{abstract}

Kata Kunci: Glucagon-like peptide 1, kolesistokinin, obesitas, skala analog visual rasa kenyang, skala analog visual rasa lapar

Correspondence: Dian Handayani. Department of Nutrition Faculty of Medicine Universitas Brawijaya Malang, Jl. Veteran Malang 65145 Tel.082143686424Email:handayani_dian@ub.ac.id

DOI: http://dx.doi.org/10.21776/ub.jkb.2020.031.01.X 


\section{INTRODUCTION}

Obesity is an emerging health issue in Indonesia and worldwide. The prevalence of obesity in Indonesia rose gradually and was $19.7 \%$ for male and $32.9 \%$ for female adults in 2013 (1). Numerous factors such as energy imbalance, changes in dietary patterns, and lifestyle have been identified as obesity-related factors. Long-term and excessive intake of food with a high density of calories and a reduction in physical activity might increase the risk of obesity (2). Our previous study revealed that fast-food has a high energy density compared to homemade food (3). Currently, the availability and accessibility of fast food are increasing; thus, the risk of becoming obese or overweight is also increasing (4).

Obesity is often associated with excess fat accumulation in adipose tissue due to increase in leptin production (5). Leptin is a hormone that serves as the primary regulator of satiety and is involved in the biochemical response to food. In obese individuals, leptin levels are persistently high due to overeating, which causes leptin receptor down regulation and leads to a decrease in the sensitivity of the hormone. The loss of sensitivity to leptin and leptin receptors causes uncontrolled appetite, resulting in an increased risk of obesity $(5,6)$.

Alterations in satiety hormone levels play a role in obesity metabolism. The hormones glucagon-like peptide 1 (GLP1) and cholecystokinin (CCK) play an essential role in the regulation of hunger and satiety indicators in humans. The GLP-1 hormone that is produced by $L$ cells in the gastrointestinal tract is classified as an incretin, which stimulates insulin secretion. The incretins are stimulated by the presence of nutrients, especially carbohydrates and fats, in the lumen of the small intestine (7). Cholecystokinin and leptin are two important peptides with pertinent effects on feeding and body weight control (8). Cholecystokinin is secreted from intestinal I cells in response to fatty acids and proteins in the intestinal lumen $(9,10)$. In addition to the hormonal response, the satiety response can be measured on the visual analogue scale (VAS). Some experimental studies using the VAS as a method to record appetite sensations found the scale to be a very sensitive subjective measurement tool (11).

There are some studies that have shown controversial results about satiety levels in obesity, which needed further investigation. For this reason, the authors demonstrated the direct effect of iso caloric fast food consumption on satiety hormones. Furthermore, this study aimed to determine the differences in the satiety response between healthy-weight and obese adult men after consuming iso caloric fast food, by analyzing the levels of GLP-1 and CCK, the subjective responses (VAS hunger and fullness rating), and the relationships between the VAS hunger and fullness ratings and both GLP-1 and CCK.

\section{METHODS}

\section{Subjects}

Two groups of male respondents aged $20.6 \pm 1.08$ years old who were either obese (BMI $\left.25-27.5 \mathrm{~kg} / \mathrm{m}^{2}\right)$ or within a healthy weight range (BMI $18.5-24.9 \mathrm{~kg} / \mathrm{m}^{2}$ ) with 16 individuals from each group used in this study. Only male subjects were included to avoid a sex bias. Individuals in both groups were declared healthy through screening and did not suffer from hypercholesterolemia, diabetes mellitus, or hypertension. The blood glucose and cholesterol were tested using simple method by prick the respondent finger with small, sharp needle and put a drop of blood on a test strip a 3-in-1 Multi-monitoring SystemAuto check (General Life Biotechnology Co., LTD., Taiwan). To test plasma leptin, a sandwich ELISA (CAN-L 4260/Diagnostic Biochem Canada Inc. London, Ontario, Canada) was performed. This study was approved by the Ethics Committee of the Faculty of Medicine, University of Brawijaya (389/EC/KEPK/07/2015), and all respondents signed the informed consent form.

\section{Research Design}

A time series study design was used, and the study was conducted in Malang city involving sixteen volunteer students from University of Brawijaya University due to convenient accesibility. Each respondent fasted for 10-12 hours on the night prior to consuming fast food at breakfast the following day. At $7 \mathrm{am}, 5 \mathrm{ml}$ blood from vein each respondent was collected, and the VAS score was recorded (time 0); participants then consumed fast food containing the same amount of energy. Blood was collected and the VAS score recorded again at 30,60 , and 120 minutes after eating.

\section{Fast Food}

The fast food used in this research was obtained from franchise restaurants in Malang City and was provided to the participants for breakfast. All these foods have approximately the same number of calories (500-600kcal) and meet $25 \%$ of the participants' energy needs based on the Nutrition Adequacy Score for Indonesian men aged 1929 years (12). Energy, water, protein, fat and fiber were analyzed as explained in our previous study (13). The measurements of energy and macronutrients in the fast food used in this study had been reported in other publication (14).

\section{Blood Sampling and Biochemical Analysis}

Plasma samples obtained from the blood samples of each respondent were centrifuged at 3000rpm and incubated at $25^{\circ} \mathrm{C}$ for 10 minutes. A PLC-05 tabletop centrifuge (Gammy Industrial Corporation, Taiwan in association with Cannic. Inc., USA) was used for separating plasma. Levels of the satiety hormone GLP-1 were measured using a sandwich enzyme-linked immunosorbent assay (ELISA) (E-EL-H0148; Elabscience Biotechnology, China). Levels of the satiety hormone CCK were measured using a sandwich enzymelinked immunosorbent assay (ELISA) for Human CCK-8 (Cholecystokinin 8) (E-EL-H0723; Elabscience Biotechnology, China). The standards and plasma samples were placed into the wells of a microtiter plate containing specific antibodies (anti-GLP-1) from E-EL-H0148 (Elabscience Biotechnology, China) and incubated at $37^{\circ} \mathrm{C}$ for 90 minutes. Specific biotinylated detection antibodies and streptavidin-HRP conjugates were then added to each well of themicroplate, which was incubated at $37^{\circ} \mathrm{C}$ for 90 minutes. The substrate and a stop solution were added in a darkroom until the color changed. The optical densities (ODs) were measured using an ELISA plate reader at a wavelength of $450 \pm 2 \mathrm{~nm}$. Hormone concentrations in the samples were calculated by comparing the OD values of the samples against those of the standards.

\section{Hunger and Fullness}

Respondents were asked to complete a VAS form $(15,16)$, which included parameters of hunger (Q1) and fullness (Q2), and the responses were obtained at 0 minutes (before eating), 30 minutes, 60 minutes, and 120 minutes after eating. The VAS form was completed by marking a vertical 
line in order to describe the respondent's hunger and fullness.

\section{Statistical Analysis}

The results are reported as the mean \pm SD. The overall postprandial responses were assessed for each parameter as the area under the curve (AUC) using the trapezoid rule. Tests for the different respondent characteristics, VAS Q1 (hunger) and Q2 (fullness), total AUC VAS Q1 (hunger) and total AUC VAS Q2 (fullness), and GLP-1 and CCK levels at 0 and 120 minutes between the healthy-weight and obese men were carried out using an unpaired t-test (the data were normally distributed and homogenous). In addition, the total AUC GLP-1, total AUC CCK, and GLP-1 levels at 30 and 60 minutes were tested using the Mann-Whitney $U$ test (the data were not normally distributed and homogenous). The correlation between the total AUC GLP-1 and total AUC CCK with the total AUC VAS Q1 and Q2 were assessed using Pearson's correlation analysis (the data were normally distributed and homogenous). These statistical analyses were performed using IBM SPSS Statistics for Windows version 22 (IBM Corp, Armonk, NY, USA). P-value $<0.05$ are considered to be statistically significant. Two groups of male respondents aged $20.6 \pm 1.08$ years old. Both groups (obese and overweight) were tested using unpaired t-tests. All demographic and anthropometric characteristics showed significant differences between the healthy-weight and obese respondents except age, height, and random blood glucose levels (17).

\section{RESULTS}

Hormone GLP-1

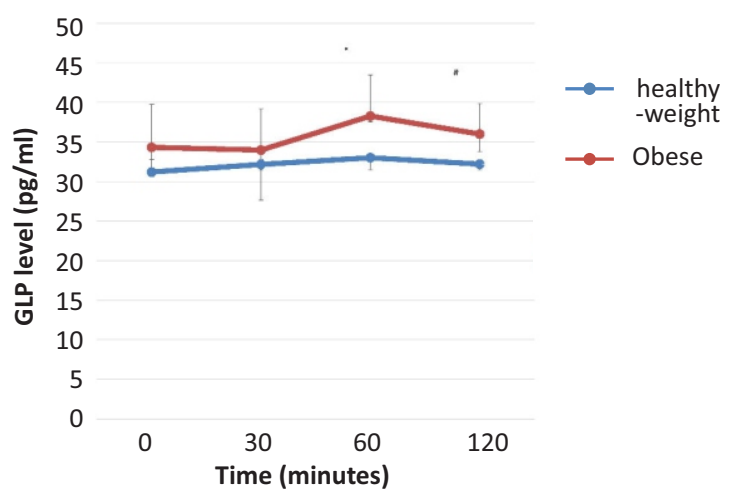

Figure 1. GLP-1 level in healthy-weight and obese respondents in all time series

Note: The data are presented as mean \pm SD (error bars), *Significant difference between groups by the Mann-Whitney $U$ test (data were not normally distributed and homogenous), \#Significant difference between groups by unpaired t-test (data were normally distributed and homogenous). P value 0.05 is considered statistically significant

GLP-1 levels were increased in both groups of respondents in all time series. Both groups were analyzed using unpaired t-tests for GLP-1 levels at 0 and 120 minutes. The GLP-1 levels at 30 and 60 minutes were analyzed using the Mann-Whitney $U$ test. Significant differences were found only at 60 minutes and 120 minutes ( $p=0.001, p=0.002)$, in which the group of obese respondents had higher values than those of the group of healthy-weight respondents. The plasma GLP-1 levels of the healthy-weight respondents were $31.20 \pm 5.45 \mathrm{pg} / \mathrm{ml}$ (0 minutes), $32.16 \pm 5.25 \mathrm{pg} / \mathrm{ml}$ (30 minutes), $33.01 \pm 5.22 \mathrm{pg} / \mathrm{ml}$ (60 minutes), and $32.20 \pm 3.88 \mathrm{pg} / \mathrm{ml}$ (120 minutes). The plasma GLP-1levels of the obese respondents were $34.32 \pm 3.37 \mathrm{pg} / \mathrm{ml}$ (0 minutes), $33.98 \pm 6.32 \mathrm{pg} / \mathrm{ml}$ (30 minutes), 38.27 $\pm 0.79 \mathrm{pg} / \mathrm{ml}(60$ minutes), and $36.00 \pm 2.25 \mathrm{pg} / \mathrm{ml}$ (120 minutes). These results are shown in Figure 1.

\section{Hormone CCK}

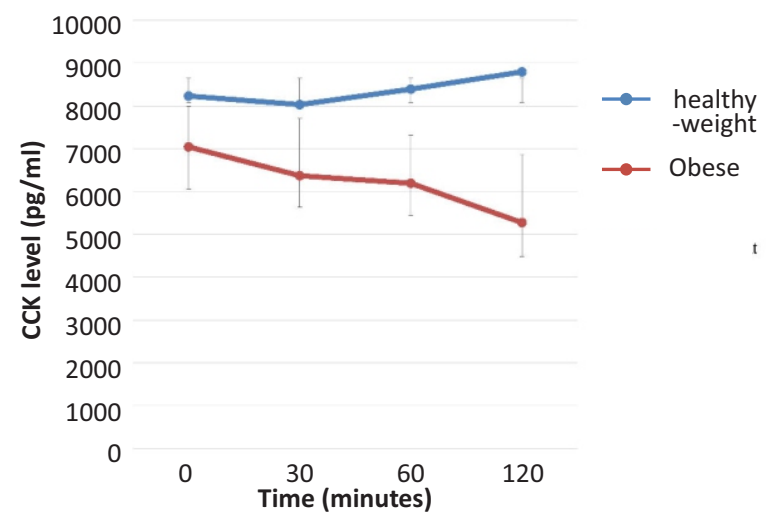

Figure 2. CCK level in healthy-weight and obese respondents in all time series

Note: The data are presented as the mean \pm SD (error bars). *Significant difference between groups by unpaired t-test. $P$ value 0.05 is considered statistically significant

Levels of CCK in both groups were analyzed using unpaired t-tests. Levels of CCK were higher in healthy-weight respondents than in obese respondents. The plasma CCK levels of healthy-weight respondents were $8.23 \pm 0.95$ (x103) $\mathrm{pg} / \mathrm{ml}$ (0 minutes), $8.03 \pm 1.33$ (x103) pg/ml (30 minutes), $8.39 \pm 1.13(x 103) \mathrm{pg} / \mathrm{ml}$ (60 minutes), and $8.80 \pm 1.60(x 103) \mathrm{pg} / \mathrm{ml}$ (120 minutes). The plasma CCK levels of obese respondents were $7.05 \pm 0.98(x 103) \mathrm{pg} / \mathrm{ml}$ (0 minutes), $6.37 \pm 0.74(\times 103) \mathrm{pg} / \mathrm{ml}$ (30 minutes), $6.20 \pm 0.75(x 103) \mathrm{pg} / \mathrm{ml}$ (60 minutes), and $5.28 \pm 0.79(x 103)$ $\mathrm{pg} / \mathrm{ml}$ (120 minutes). These results are shown in Figure 2.

\section{VAS Hunger and Fullness Ratings}



Figure 3. GLP-1 level in healthy-weight and obese respondents in all time series

Note: The data are presented as the mean \pm SD (error bars), * Significant difference between groups by unpaired t-test. P value 0.05 is considered statistically significant. 
The VAS hunger rating both in healthy-weight and obese respondents shows the same chart pattern, high during the time before eating and then decreasing within 30 minutes after the meal. The rating increased slowly over time in the 60- and 120-minute recordings. Based on the statistics, data at 0,30 , and 60 minutes showed no significant differences between the healthy-weight and obese respondents at each time $(p=0.511, p=0.651$, $\mathrm{p}=0.116)$, but VAS hunger ratings at 120 minutes after eating showed a significant difference between healthyweight and obese respondents $(p=0.049)$. These results are shown in Figure 3.

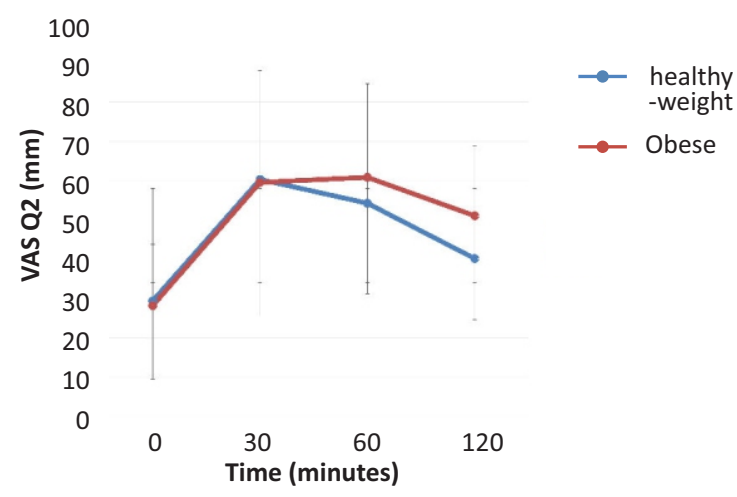

Figure 4. VAS Q2 (fullness) level in healthy-weight and obese respondents in all time series

Note: The data are presented as the mean \pm SD (error bars), * Significant difference between groups by unpaired t-test. $P$ value 0.05 is considered statistically significant

The VAS fullness rating both in healthy-weight and obese respondents showed an inverse pattern to that of the VAS hunger ratings. The VAS fullness rating was low before a meal and then rose during the 30 minutes after a meal, showing a slow decrease at 60 and 120 minutes after eating. Based on the statistics, there were no significant differences between healthy-weight and obese respondents $(p=0.843$ at 0 minutes, $p=0.947$ at 30 minutes, $p=0.493$ at 60 minutes, and $p=0.183$ at 120 minutes after eating). These results are shown in Figure 4.

\section{Area Under the Curve (AUC)}

The data for the AUC were computed by the trapezoid measure and more readily as the means of all the data points for each respondent. The area under the curve in both respondent groups showed significant differences in hormone levels in all time series (total AUC GLP-1 p <0.002, total AUC CCK $p<0.001$ ), but there were no significant differences in VAS series (total AUC VAS Hunger $p=0.127$, total AUC VAS Fullness $p=0.511$ ). These results are shown in Table 1.

Table 1. Tests of total AUC for GLP-1, CCK, VAS hunger and VAS fullness

\begin{tabular}{lrrr}
\hline \multicolumn{1}{c}{ Total AUC O-120 } & Obese $(\mathbf{n = 1 6 )}$ & \multicolumn{1}{c}{$\begin{array}{c}\text { Healthy-weight } \\
(\mathbf{n}=\mathbf{1 6})\end{array}$} & P-value \\
\hline GLP-1 $\left(\times 10^{3}\right)(\mathrm{pg} . \mathrm{min} / \mathrm{ml})$ & $4.34 \pm 0.21$ & $3.88 \pm 0.47$ & $0.002^{*}$ \\
CCK $\left(\times 10^{3}\right)(\mathrm{pg} . \mathrm{min} / \mathrm{ml})$ & $733.87 \pm 50.70$ & $1006.29 \pm 111.45$ & $<0.001^{*}$ \\
VAS Hunger $\left(\times 10^{3}\right)(\mathrm{mm} . \mathrm{min})$ & $2.64 \pm 1.39$ & $3.43 \pm 1.45$ & 0.127 \\
VAS Fullness $\left(\times 10^{3}\right)(\mathrm{mm} . \mathrm{min})$ & $6.47 \pm 2.74$ & $5.89 \pm 2.17$ & 0.511 \\
\hline Note: * Significant difference between groups by the Mann-Whitney U
\end{tabular}

test. $P$ value 0.05 is considered statistically significant

Correlation between Hormone GLP-1 and CCK levels, VAS Hunger, and Fullness Rating

No significant correlations were found between total AUC GLP-1 and total AUC CCK with total AUC VAS Q1 (hunger) and Q2 (fullness) in either the healthy-weight or obese respondent groups ( $p>0.05$ ) (Table 2 ).

\section{DISCUSSION}

The increasing of GLP-1 secretion was stimulated by nutrient on the intestine expecially carbohidrate and fat. The digestion process affect on the time and number of GLP-1 plasma level. Total GLP-1 containing active GLP-1 (7$36)$ and inactive GLP-1 (9-36) reflects the total amount of GLP-1 secreted by L cells in the intestine. Active GLP-1 (736 ) is involved in the secretion of insulin, glucagon, gastric emptying, and satiety of the appetite. Inactive GLP-1 (9$36)$ increases the uptake of glucose into cells in order to stabilize blood sugar (18). In this study, GLP-1 levels in obese respondents were significantly higher than those in healthy-weight respondents. In contrast, some previous studies stated that GLP-1 levels in obese respondents were lower than those in lean individuals (19).

Nevertheless, the reduction in the mechanism of release of GLP-1 in obese individuals still cannot be explained with certainty (20). However, the data suggest that a decrease in GLP-1 is not always observed in obesity (21). In contrast, this study showed that average overall levels of GLP-1 were higher in obese respondents. This phenomenon was also

Table 2. Relationship between GLP-1 levels and VASQ1 (hunger) and VAS Q2 (fullness) rating

\begin{tabular}{|c|c|c|c|c|c|}
\hline & $\begin{array}{l}\text { Total AUC GLP-1 } \\
\left(\times 10^{3}\right) \text { (pg.min/ml) }\end{array}$ & $\begin{array}{l}\text { Total AUC VAS Q1 } \\
\left(\times 10^{3}\right) \text { (mm.min) }\end{array}$ & $\begin{array}{c}\text { Total AUC VAS Q2 } \\
\left(\times 10^{3}\right) \text { (mm.min) }\end{array}$ & $\mathbf{R}$ & P-value \\
\hline \multirow{2}{*}{$\begin{array}{l}\text { Healthy } \\
\text { weight }\end{array}$} & \multirow{2}{*}{$3.88 \pm 0.47$} & $3.43 \pm 1.45$ & \multirow{3}{*}{$5.89 \pm 2.17$} & -0.061 & 0.821 \\
\hline & & & & -0.022 & 0.937 \\
\hline \multirow{3}{*}{ Obese } & \multirow{2}{*}{$4.34 \pm 0.21$} & \multirow[t]{2}{*}{$2.64 \pm 1.39$} & & -0.068 & 0.801 \\
\hline & & & \multirow{2}{*}{$\begin{array}{l}6.47 \pm 2.74 \\
\text { otal AUC VAS Q2 } \\
\left.\times 10^{3}\right) \text { (mm.min) }\end{array}$} & -0.163 & 0.546 \\
\hline & $\begin{array}{c}\text { Total AUC CCK } \\
\left(\times 10^{3}\right)(\mathrm{pg} \cdot \mathrm{min} / \mathrm{ml})\end{array}$ & $\begin{array}{l}\text { Total AUC VAS Q1 } \\
\left(x 10^{3}\right) \text { (mm.min) }\end{array}$ & & $\mathbf{R}$ & P-value \\
\hline \multirow{2}{*}{$\begin{array}{l}\text { Healthy } \\
\text { weight }\end{array}$} & \multirow{2}{*}{$1006.29 \pm 111.45$} & $3.43 \pm 1.45$ & & -0.262 & 0.328 \\
\hline & & & \multirow[t]{2}{*}{$5.89 \pm 2.17$} & -0.325 & 0.220 \\
\hline \multirow{2}{*}{ Obese } & \multirow{2}{*}{$733.87 \pm 50.70$} & \multirow[t]{2}{*}{$2.64 \pm 1.39$} & & -0.054 & 0.842 \\
\hline & & & $6.47 \pm 2.74$ & 0.003 & 0.991 \\
\hline
\end{tabular}


reported in research conducted by Nakajima et al., in which a study was conducted on Wistar rats to observe their response to the production of postprandial GLP-1 after treatment with high-fat foods high in sucrose (High FatHigh Sucrose/HFHS). The study aimed to determine the responses of GLP-1 and insulin resistance to progressive diet-induced obesity. The results showed that during the 8 weeks of observation, the levels of GLP-1 and insulin response in the subjects fed a HFHS diet were higher than those in control subjects and subjects on a restricted diet. However, the intestinal mucosal hormone mRNA levels remained unchanged (22). This suggests that the postprandial GLP-1 response was increased during progressive glucose intolerance induced by diet and obesity in rats. The increased GLP-1 secretion in rats fed a chronic HFHS diet is a mechanism to increase the sensitivity of the gut to luminal nutrients, and it aims to slow down the formation of glucose intolerance and obesity.

In our study, we showed that the total AUC of GLP-1 levels was higher in obese respondents than that in healthyweight respondents and that this may be caused by the same mechanism as that operating in the research conducted by Nakajima et al., in which diet-induced glucose intolerance and obesity increased GLP-1 levels (22). This is supported by the comparison of the respondent characteristics showing that random blood glucose levels were not significantly different between the healthy-weight and obese respondents $(p=0.159)$.

Shah $M$ and Vella $A$, have reported that the average handling of food and digestion in the gut is increased in obese individuals and is characterized by hyperplasia of the gastrointestinal mucosa including endocrine cells (23). These findings support the idea that increased secretion of insulinotropic hormones, including GLP-1, will lead to hyperinsulinemia. As reported by Madsbad et al., the impaired incretin effect observed in patients with obesity mainly occurs with the potential reduction in insulinotropic GLP-1 and then the decrease in GLP-1 secretion (24). This explains the role of GLP-1 in terms of its role in gastric emptying, food intake, and controlling glucose levels and that if it is impaired, it will lead to impaired incretins, hyperglycemia, weight gain, and so on. Some of the above research supports these results in that the levels of GLP-1 were higher in obese respondents than those in healthy-weight respondents possibly because the obese respondents in this study are undergoing the progression of glucose intolerance induced by diet.

Higher levels of CCK in healthy-weight respondents may be caused by higher leptin levels, especially duodenal leptin, which stimulates the secretion of CCK hormones. In this research, leptin was measured at higher levels in obese respondents comparing to those in healthy-weight adult men. An in vivo study has shown that duodenal leptin can modulate the release of CCK hormones (25). Apparently high leptin levels in obese respondents did not reflect optimal activity, as shown in this study. Most obese individuals show increased food intake despite high circulating leptin levels, implying a state of leptin resistance, i.e., reduced responsiveness to the appetiteand weight gain-suppressing effects of leptin $(26,27)$. Over nutrition due to a high-fat diet is thought to be both a cause and an effect of leptin resistance that may be induced in the absence of obesity by acting on leptinresponsive neurons, and leptin resistance in obesity may maintain over nutrition (28). Various mechanisms have been proposed to mediate leptin resistance such as hypothalamic inflammation (29).

In this study, the responses of GLP-1 and CCK levels in the healthy-weight and obese respondents were not influenced by the type of food consumed (fast food) but rather by the physiological state of each group of respondents in response to the presence of food. There was no significant difference between the value of VAS Q1 (hunger) and VAS Q2 (fullness) in the healthy-weight and obese groups of respondents. This is because the VAS is influenced more by the subjective perception of food, such as the kind of food, satiety level, palatability, social setting, culture, education, income, portion size, and even mood (30). In both groups of respondents, levels of GLP-1 and CCK did not correlate significantly with the VAS Q1 (hunger) and VAS Q2 (fullness). This finding is supported by Melhorn et al., who reported that blocking GLP-1 receptors failed to decrease appetite and increased the food intake in humans and that it was not related to the personal response for satiety (VAS) (31). There are limitations in this research that need to be considered, such as the significant difference in CCK levels between the obese and healthy-weight respondents at baseline that might influence the final intervention result. Furthermore, the wide range of nutrient contents in fast food also affects stimulation by hormonal release. Even though there were some limitations, this is the first study which examines the satiety response of fast food between two different groups. The high GLP-1 plasma levels and the low CCK levels could be further predictors of obesity. Therefore, future research needs to validate the sensitivity and specificity of GLP-1 and CCK as predictors of obesity using receiver-operating characteristic (ROC) curve analysis.

Plasma GLP-1 levels were higher in obese than in healthyweight men, possibly reflecting glucose intolerance progression in obesity. Plasma CCK levels were higher in healthy-weight weight men than those in obese men, possibly due to the impact of leptin resistance in obese men. There were no differences between VAS hunger and VAS fullness in healthy-weight and obese subjects, and the VAS did not show a correlation with levels of GLP-1 and CCK, which may be due to a number of factors that influence VAS. The changes in GLP-1 and CCK plasma levels, which are satiety hormones, must be considered predictors of obesity in the future.

This study discovered different responses of GLP-1 and CCK between obese and healthy-weight men who consumed fast food with a similar nutrient content. This study will help researchers understand the possible mechanisms underlying the increase in plasma GLP-1 levels and the decrease in CCK levels in obese adult men compared to those in healthy-weight adult men. This finding should be considered when determining specific markers for the intervention of obesity.

\section{ACKNOWLEDGEMENT}

This research was funded by a Leading Research University Grant from the Ministry of Research, Technology, and Higher Education, Republic of Indonesia (007/Add/SP2H/PL/DIT. LITABMAS/V/2015).

\section{CONFLICT OF INTEREST}

The authors declare that there is no conflict of interest. 
I warrant that the manuscript is original and its figure, substance, or tables have not been previously published. This study is part of the same project reported by Andarini

\section{REFERENCES}

1. Board HR. Basic Health Research. Jakarta: Mohro Editor; 2013.

2. Rolls BJ, Roe LS, and Meengs JS. Portion Size Can Be Used Strategically to Increase Vegetable Consumption in Adults. The American Journal of Clinical Nutrition. 2010; 91(4): 913-922.

3. Rahmawati $W$ and Handayani D. Different Recipes and Energy Density of Indonesia Fast Food on Percentage of Indonesian Daily Value. Obesity \& Control Therapies. 2014; 1(1): 1-5.

4. Currie J, DellaVigna S, Moretti E, and Pathania V. The Effect of Fast Food Restaurants on Obesity and Weight Gain. American Economic Journal: Economic Policy. 2010; 2(3): 32-63.

5. Myers MG Jr., Leibel RL, Seeley RJ, and Schwartz MW. Obesity and Leptin Resistance: Distinguishing Cause from Effect. Trends in Endocrinology and Metabolism. 2010; 21(11):643-651.

6. Attie AD and Scherer PE. Adipocyte Metabolism and Obesity. Journal of Lipid Research. 2009; 50: S395S399.

7. Holst JJ. The Physiology of Glucagon-Like Peptide 1. Physiological Reviews. 2007; 87(4): 1409-1439.

8. Perry B and Wang Y. Appetite Regulation and Weight Control: The Role of Gut Hormones. Nutrition \& Diabetes. 2012; 2(1): 1-7.

9. Sundaresan S, Shahid R, Riehl TE, et al. CD36Dependent Signaling Mediates Fatty Acid-Induced Gut Release of Secretin and Cholecystokinin. Federation of American Societies for Experimental Biology Journal. 2013; 27(3): 1191-1202.

10. Wang Y, Chandra R, Samsa LA, et al. Amino Acids Stimulate Cholecystokinin Release Through the Ca2+-Sensing Receptor. The American Journal of Physiology. Gastrointestinal and Liver Physiology. 2011; 300(4): G528-G537.

11. Klimek L, Bergmann KC, Biedermann T, et al. Visual Analogue Scales (VAS): Measuring Instruments for the Documentation of Symptoms and Therapy Monitoring in Cases of Allergic Rhinitis in Everyday Health Care: Position Paper of the German Society of Allergology (Aeda) and the German Society of Allergy and Clinical Immunology (DGAKI), ENT Section, in Collaboration with the Working Group on Clinical Immunology, Allergology and Environmental Medicine of The German Society of Otorhinolaryngology, Head and Neck Surgery (DGHNOKHC). Allergo Journal International. 2017; 26(1): 16-24.

12. Kementerian Kesehatan Republik Indonesia. Peraturan Menteri Kesehatan Republik Indonesia No: 28 Tahun 2019 Tentang Angka Kecukupan Gizi yang Dianjurkan Bagi Bangsa Indonesia. Jakarta: Kementerian Kesehatan Republik Indonesia; 2019. et al. The previous study reported the plasma acylated ghrelin in obese and normal weight men which is different with our present study.

13. Handayani D, Oktafiani LDA, Abednego RT, and Andarini S. Effect of International and Indonesian Fast Foods on Plasma Ghrelin and Glucagon Like Peptide-1 (GLP-1) Levels, Hunger and Satiety Scores is Similar in Obese Adults. Pakistan Journal of Nutrition. 2017; 16(1): 38-44.

14. Handayani D, Rahmawati W, Kusumastuty I, Harti LB, Wahyuni ES, and Andarini S. Plasma Ghrelin, PYY and CCK Concentration Following Indonesian Fast Food and Western Fast Food in Obese Participant. Food and Nutrition Sciences. 2016; 7(9): 724-731.

15. Flint A, Raben A, Blundell J, and Astrup A. Reproducibility, Power and Validity of Visual Analogue Scales in Assessment of Appetite Sensations in Single Test Meal Studies. International Journal of Obesity. 2000; 24: 38-48.

16. Flint A, Moller BK, Raben A, et al. Glycemic And Insulinemic Responses As Determinants Of Appetite In Humans. The American Journal of Clinical Nutrition. 2006; 84(6): 1365-1373.

17. Ravassa S, Zudaire A, and Diez J. GLP-1 and Cardioprotection: From Bench to Bedside. Cardiovascular Research. 2012; 94(2): 316-323.

18. Andarini S, Kangsaputra FB, and Handayani D. Preand Postprandial Acylated Ghrelin in Obese and Normal Weight Men. Asia Pacific Journal of Clinical Nutrition. 2017; 26(1): S85-S91.

19. Verdich C, Toubro S, Buemann B, Lysgard Madsen J, Juul Holst J, and Astrup A. The Role of Postprandial Releases of Insulin and Incretin Hormones in MealInduced Satiety-Effect of Obesity and Weight Reduction. International Journal of Obesity and Related Metabolic Disorders. 2001; 25(8): 1206-1214.

20. Rask E, Olsson T, Soderberg S, et al. Impaired Incretin Response after a Mixed Meal is Associated with Insulin Resistance in Nondiabetic Men. Diabetes Care. 2001; 24(9): 1640-1645.

21. Vilsboll T, Krarup T, Sonne J, et al. Incretin Secretion in Relation to Meal Size and Body Weight in Healthy Subjects and People with Type 1 and Type 2 Diabetes Mellitus. The Journal of Clinical Endocrinology and Metabolism. 2003; 88(6): 2706-2713.

22. Nakajima S, Hira T, and Hara H. Postprandial Glucagon-Like Peptide-1 Secretion is Increased During the Progression of Glucose Intolerance and Obesity in High-Fat/High-Sucrose Diet-Fed Rats. The British Journal of Nutrition. 2015; 113(9): 1477-1488.

23. Shah $M$ and Vella A. Effects of GLP-1 on Appetite and Weight. Reviews in Endocrine \& Metabolic Disorders. 2014; 15(3): 181-187.

24. Madsbad S. The Role of Glucagon-Like Peptide-1 Impairment in Obesity and Potential Therapeutic Implications. Diabetes, Obesity \& Metabolism. 2014; 16(1): 9-21.

25. Guilmeau S, Buyse M, Tsocas A, Laigneau JP, and 
Bado A. Duodenal Leptin Stimulates Cholecystokinin Secretion: Evidence of a Positive LeptinCholecystokinin Feedback Loop. Diabetes. 2003; 52(7): 1664-1672.

26. Zhou $Y$ and Rui L. Leptin Signaling and Leptin Resistance. Frontiers of Medicine. 2013; 7(2): 207220.

27. Balland E and Cowley MA. New Insights in Leptin Resistance Mechanisms in Mice. Frontiers in Neuroendocrinology. 2015; 39: 59-65.

28. Pandit R, Mercer JG, Overduin J, la Fleur SE, and Adan RA. Dietary Factors Affect Food Reward and Motivation to Eat. Obesity Facts. 2012; 5(2): 221-242.
29. de Git KC and Adan RA. Leptin Resistance in DietInduced Obesity: The Role of Hypothalamic Inflammation. Obesity Reviews: An Official Journal of the International Association for the Study of Obesity. 2015; 16(3): 207-224.

30. Green SM, Delargy HJ, Joanes D, and Blundell JE. A Satiety Quotient: A Formulation To Assess The Satiating Effect Of Food. Appetite. 1997; 29(3): 291304.

31. Melhorn SJ, Tyagi V, Smeraglio A, Roth CL, and Schur EA. Initial Evidence that GLP-1 Receptor Blockade Fails to Suppress Postprandial Satiety or Promote Food Intake in Humans. Appetite. 2014; 82: 85-90. 